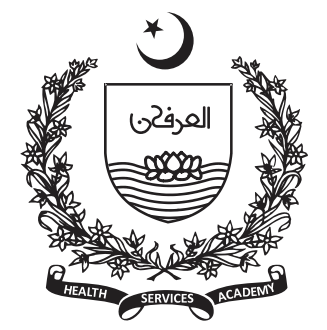

1Independent public health consultant, Lahore,

Pakistan

2Stop TB Partnership,

Geneva, Switzerland

Corresponding Author:

Farihah Malik

Email: farihahm@unops.org

\section{Innovative approaches to end TB in Pakistan: a review of TB REACH projects from 2010 to 2020}

Farihah Malik ${ }^{1}$, Jacob Creswell ${ }^{2}$

\section{Abstract}

Background: TB REACH is a grant-making initiative launched by the Stop TB Partnership in January 2010 to support innovative approaches and technologies to find and treat people with active TB disease, drugresistant TB, or TB infection. Since then, TB REACH has launched eight Waves of funding to pilot untested, but promising technologies, tools, and approaches. The objective of this paper was to review the grants implemented in Pakistan in the decade since TB REACH's inception and to summarize the approaches used, document the results, and assess the impact of these projects on local and international policy.

Methods: We searched the TB REACH's Grant Management System (GMS), which is a database for information on all grants awarded through the initiative, for recipient organisations in Pakistan from 2010 until June 2020. Data was abstracted for the following topic areas: type of grant, focus of work, case finding strategies, risk groups screened and impact on case finding.

Results: Through eight waves of funding, TB REACH has supported 28 grants for 21 different interventions in Pakistan worth a total of USD 13.4 million. Overall, 19 of these projects aimed to improve detection, linkage to treatment and reporting of TB and two were product innovation grants for developing resources and materials to aide TB service delivery.

Conclusion: TB REACH support has facilitated the introduction of new technologies, establishment of innovative processes in both public and private sector and approaches for addressing TB in key populations. The TB response in Pakistan and globally will continue to require innovation and disruption of 'business as usual' approaches if we are to End TB.

Keywords: Tuberculosis, innovation, active case finding, public private engagement, technology, key populations 


\section{Introduction}

7 uberculosis (TB) continues to be the leading cause of death from an infectious disease. A large reason for this is because about ten million people around the world become ill with TB each year, yet almost one-third of them fail to get an accurate diagnosis or effective treatment (1). They are missed by the TB response. Pakistan has one of the highest TB burdens in the world, currently more than half a million people every year are estimated to develop TB, but more than a third of them remain undiagnosed, untreated and are not notified to national authorities (1). To end $\mathrm{TB}$ as a global epidemic everyone with TB must be identified and treated properly, albeit with TB infection, or drug sensitive or drug resistant forms of the disease (2).

After a long period of the expansion of TB services under directly observed treatment, short course (DOTS) and corresponding increase in case notifications in the first decade of the century, the progress began to stagnate in $2008(3,4)$. Part of the reason for lack of progress in ending TB has been the passive nature of the TB response, built on the DOTS Strategy of the 1990s and hampered by the reluctance and delay in embracing new opportunities, developing and implementing new tools and drugs $(4,5)$.

The TB REACH initiative was launched by the Stop TB Partnership in January 2010 in response to a call from partners and high burden countries to support innovative approaches to reach more people who have TB and link them to care. TB REACH is supported by Global Affairs Canada, United States Agency for International Development (USAID), and the Bill and Melinda Gates Foundation. Since its inception, TB $\mathrm{REACH}$ has launched eight rounds (or Waves) of funding and expanded in scope to fund innovative approaches and technologies aimed at increasing the number of people diagnosed and treated for $\mathrm{TB}$, decreasing treatment time and improving treatment success rates (6). TB REACH's mandate includes the ability to fund interventions that are not yet part of global recommendations, taking risks to pilot untested, but promising technologies, tools, and approaches. TB REACH accepts applications from all types of not-for-profit and governmental organizations, allowing a wide range of partners to propose and test new ideas.

Globally, TB REACH has supported 326 grants in 54 countries which have resulted in more than 40 million people being screened for $\mathrm{TB}$ and more than 2.6 million people with $\mathrm{TB}$ in project areas being diagnosed and treated for TB (7). TB REACH has supported numerous grants in Pakistan as part of this funding. Previous publications have documented the performance of Wave 1 projects' impact on TB case detection (8), the comparative results of contact investigation interventions across nineteen projects implemented in eleven high burden countries (9), and a summary of early implementation experiences using Xpert MTB/RIF assay (10). In this review our aim is to summarize the approaches of TB REACH grantees in Pakistan, document their results, and assess the impact of these projects on local and international policy.

\section{Methodology}

\section{The TB REACH Mechanism}

TB REACH receives proposals through Wave-based calls for funding. Most projects focus on improving TB detection, but grants are also awarded for improving treatment outcomes and product innovation (6). Funding decisions are made by an independent Proposal Review Committee (PRC) and approved by the Stop TB Partnership Board. TB REACH follows a 'Transition to Scale Up' framework in which proposals are funded and supported in either the proof of concept, scale-up, or sustainability phase. Funded projects undergo rigorous independent monitoring and evaluation (M\&E) with the aim to link impactful projects to long-term funding for scalability and sustainability. After a baseline validation of historical data for both implementation and control populations, all projects report quarterly on both a series of process indicators documenting the screening and testing cascade or treatment adherence indicators (11). Funding generally lasts for 18 months but can be extended. In each Wave, a few promising projects are selected by the PRC to receive continued support for an additional grant. Final project reviews are developed by the grantees in addition to the separate reports from the independent $M \& E$ reviewers.

\section{Data abstraction}

We searched the TB REACH's Grant Management System (GMS), which is a database for information on all grants awarded through the initiative, for recipient organisations in Pakistan from Wave 1 in 2010 until June 2020. Data in the summary reports was abstracted in relation to the following topic areas: type 
of grant, focus of work, case finding strategies, risk groups screened and impact on case finding.

No ethics approval was required for this abstraction of aggregated TB REACH reporting data. Many projects requested their own ethical approval for individual activities and research.

\section{Results}

\section{Overview of TB REACH projects in Pakistan}

Through eight waves of funding from 2010 to 2020, TB REACH has supported 28 grants for 21 different projects/interventions in Pakistan worth a total of USD 13.4 million. Table 1 shows an overview of these projects. Overall, 19 of these projects aimed to improve detection, linkage to treatment and reporting of TB and two were product innovation grants for developing TB resources and materials to aide service delivery and performance. Since 2010, TB REACH interventions have been implemented across 50 districts of Pakistan, most in Sindh and Punjab, with one project in Balochistan - the geographic spread of interventions is depicted in Figure 1.

Seven of the 21 interventions that demonstrated impact during the first year of implementation secured scale-up funding from TB REACH to continue activities for a second year and provide larger-scale service delivery. The budgets presented in Table 1 include the total amount awarded for implementation during year 1 and during scale up (for those projects that secured scale up).

Together these projects (Waves 1-6) were responsible for screening over 3 million people and testing 126,860 people for TB. Results from Wave 6 scale up, Wave 7 and 8 are not yet available as interventions are still underway.

Table 1 Overview of TB REACH projects in Pakistan

\begin{tabular}{|c|c|c|c|c|c|}
\hline $\begin{array}{l}\text { Year } \\
\text { /Wave }\end{array}$ & Organization & $\begin{array}{c}\text { Total budget } \\
\text { USD }\end{array}$ & Funding track & $\begin{array}{l}\text { Implementatio } \\
\text { n province }\end{array}$ & $\begin{array}{l}\text { Scale } \\
\text { up } \\
\text { fundi } \\
\text { ng }\end{array}$ \\
\hline \multirow[t]{4}{*}{$2010 / 1$} & Bridge Consultants Foundation & 297,374 & Case detection & Sindh & Yes \\
\hline & The Indus Hospital & $1,021,591$ & Case detection & Sindh & Yes \\
\hline & National TB Programme & 937,023 & Case detection & Sindh & \\
\hline & Provincial TB Program, Punjab & 500,000 & Case detection & Punjab & \\
\hline \multirow[t]{2}{*}{$2011 / 2$} & Interactive Research and Development & 903,551 & Case detection & Sindh* & Yes \\
\hline & Association for Social Development & $1,822,009$ & Case detection & $\begin{array}{l}\text { Punjab and } \\
\text { Khyber } \\
\text { Pakhtunkhwa }\end{array}$ & Yes \\
\hline \multirow[t]{2}{*}{$2013 / 3$} & Interactive Research and Development & $1,200,000$ & Case detection & Sindh & \\
\hline & National TB Programme & $1,441,834$ & Case detection & $\begin{array}{l}\text { Punjab and } \\
\text { ICT }\end{array}$ & Yes \\
\hline $2014 / 4$ & The Indus Hospital & 315,962 & Case detection & Sindh & \\
\hline \multirow[t]{3}{*}{$2017 / 5$} & Interactive Health Solutions & 149,987 & $\begin{array}{l}\text { Product } \\
\text { innovation }\end{array}$ & $\mathrm{n} / \mathrm{a}$ & \\
\hline & Bridge Consultants Foundation & $1,085,860$ & Case detection & Sindh & Yes \\
\hline & Mercy Corps & 400,000 & Case detection & Sindh & \\
\hline \multirow[t]{3}{*}{$2018 / 6$} & DOPASI Foundation & 911,408 & Case detection & Balochistan & Yes \\
\hline & $\begin{array}{l}\text { The Foundation for Innovative New } \\
\text { Diagnostics }\end{array}$ & 335,780 & Case detection & National & \\
\hline & The Indus Hospital & 199,890 & Case detection & $\begin{array}{l}\text { Punjab and } \\
\text { Sindh }\end{array}$ & \\
\hline
\end{tabular}




\begin{tabular}{|c|c|c|c|c|}
\hline \multirow[t]{5}{*}{$2019 / 7$} & Community Health Solution & 291,748 & Case detection & Sindh \\
\hline & Interactive Research and Development & 397,923 & Case detection & Sindh \\
\hline & National TB Programme & 78,131 & $\begin{array}{l}\text { Product } \\
\text { innovation }\end{array}$ & $\mathrm{n} / \mathrm{a}$ \\
\hline & Bridge Consultants Foundation & 357,011 & Case detection & Sindh \\
\hline & Association for Social Development & 400,000 & Case detection & $\begin{array}{l}\text { Punjab and } \\
\text { ICT }\end{array}$ \\
\hline $2020 / 8$ & DOPASI Foundation & 399,996 & Case detection & $\begin{array}{l}\text { Punjab and } \\
\text { ICT }\end{array}$ \\
\hline Total & & $13,447,078$ & & \\
\hline
\end{tabular}

*this was a multi-country project that was implemented in Pakistan and Bangladesh

Note: Map does not show product innovation projects or interventions implemented at a provincial (NTP Wave 1) or national (FIND Wave 6) scale.

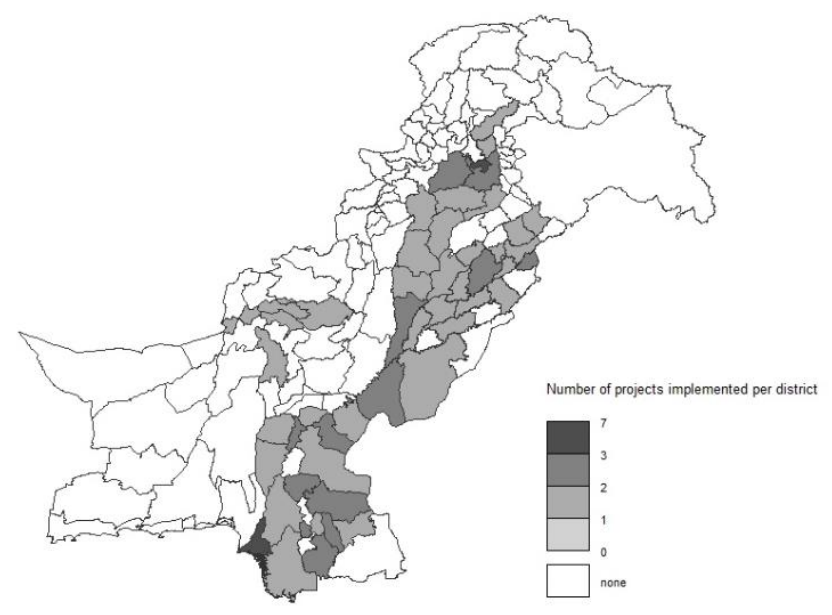

Figure 1 Number of TB REACH projects implemented per district in Pakistan (Wave 1-8)

Interventions in TB REACH projects in Pakistan Over eight funding Waves, the 21 interventions supported by TB REACH encompassed a wide range of activities and approaches. The interventions, innovations and key populations targeted are summarized for TB REACH projects in Pakistan in Table 2.

\section{Key populations}

The Global Plan to End TB describes key populations based on increased exposure to $\mathrm{TB}$, limited access to TB services, or certain biological or behavioural characteristics (2). As with other TB REACH projects, many of the interventions in Pakistan have focused on key population groups. Interventions by Bridge Consultants Foundation (Wave 1), National TB Program (NTP) (Wave 3) and Mercy Corps (Wave 5) included contacts of TB patients (12-14). In another intervention, the NTP (Wave 1) focused on urban slum dwelling populations living in close quarters and having inadequate electric and sewage systems and a lack of clean water (15). In Wave 1, Punjab Provincial TB Program (PTP) implemented active case finding for prisoners in Punjab who had limited access to health services and $\mathrm{TB}$ diagnosis and treatment. At all participating prisons, laboratories were set up and basic TB management units were established. Mass screenings were conducted for prisoners and prison staff, and all new entrants were screened upon entry. During two years of project implementation, 379,729 prisoners and prison staff were screened, resulting in the identification of $883 \mathrm{~TB}$ patients. This represented a 9-fold increase in notifications compared to the year prior to the start of the project.

Some of the key populations such as transgender women and male sex workers (MSWs) face difficulty accessing routine health services. Through recruiting influential community representatives, the Bridge Consultants Foundation (in Wave 5) was able to establish both HIV and TB screening and diagnosis for transgender women and MSWs. These key population groups and representatives of community organizations also played a role in sensitizing doctors to work with transgender and MSW. This intervention tested more than 7000 transgender women and MSWs finding more than 600 people with $\mathrm{TB}$, uncovering high rates of previously undiagnosed HIV co-infection $(16,17)$, and was able to expand its intervention to other cities in Pakistan as a result (18).

Other, TB REACH interventions concentrated on children (Indus Hospital Wave 4), those with extra pulmonary TB (Indus Hospital Wave 6) and coal miners and associated communities (Dopasi Foundation Wave 6). 


\section{Private sector engagement}

Many people who are missed by the public sector in Pakistan likely seek care in the private sector (19) and therefore many projects have focused efforts to develop different approaches around private provider engagement (PPE). Both NGO and public sector partners have tried different PPE strategies to improve TB notifications in Pakistan. Beginning in Wave 1 when both Indus Hospital and the NTP led very successful interventions, the engagement of private providers has been a large source of previously unidentified people with TB $(15,20)$. Although both successful they were quite different as Indus focused on systematic screening at private practitioners' sites while the NTP focused on large gatherings and screenings organized in conjunction with private providers and this has continued as a core model in Global Fund-supported work subsequently. The Indus Hospital project in Karachi used awareness campaigns, mobile banking to disburse incentives and community screeners to screen people for $\mathrm{TB}$ at private clinics and a large hospital. The results demonstrated that case detection doubled in one year and the Indus Hospital became the second largest reporting centre in Pakistan (20-22).

In subsequent Waves, PPE included systematic screening at private laboratories, and engagement of different laboratory networks to improve access and pricing to GeneXpert tests, and new interventions in Wave 8 that look to use data from private drug sales to target pharmacies and improve reporting when people with TB begin treatment in the private sector. Another important TB REACH launch was the development of the social enterprise model which was supported in Wave 3 including a number of new technologies and the establishment of primary care centres (called Sehatmand Zindagi Centres) which have continued and expanded under the Global Fund. This network of centres provides free or highly subsidized TB diagnostics and treatment supported by the revenue generated from other (non-TB) laboratory and radiology tests.

\section{Technology and innovations}

Often, innovation focuses on implementing or developing new technologies. TB REACH has been able to support the introduction of a number of technologies in Pakistan to evaluate how they work. Other funders often have restrictions on the type of interventions they can support and are sometimes limited to those that are already recommended in the
World Health Organization (WHO) guidelines, therefore partners have turned to TB REACH to try and test unproven but potentially impactful new tools. In Wave 2, IRD was able to introduce Xpert MTB/RIF as a TB diagnostic tool, rather than as a test for drug sensitivity testing (DST) as it was generally used at the time (23). In Wave 3 this was scaled to a higher level but was coupled with the introduction digital $x$-ray machines and artificial intelligence to read the Chest X-Ray (CXR) images $(24,25)$. More recently, Dopasi Foundation has been able to pilot the first introduction of handheld x-ray to screen people in hard-to-reach areas. In addition to these diagnostic technologies, other innovative technologies such as mobile applications to assist screening, SMS reminders for appointments and treatment adherence, mobile banking to disburse incentives, Geographic Information System (GIS) mapping and tele-health have been introduced by both public and private sector partners through TB REACH grants and many have subsequently been taken up by other donors including Unitaid and The Global Fund.

\section{Process innovation}

TB REACH grantees have employed diverse range of processes and innovative strategies for increasing detection of TB and linkage to care. As mentioned above, a number of interventions focused on contact investigation, but these were based on different approaches; Bridge Consultants Foundation (Wave 1) trained lay personnel (community mobilisers) for active contact screening with transport support while the Mercy Corps (Wave 5) intervention relied on trained community health workers (LHWs) for active case finding. In Wave 3, NTP used GIS mapping to screen all people staying within a radius of 50 metres from the household of a person with TB. In addition, Indus hospital (Wave 4) used reverse contact tracing as part of their child TB screening programme), by screening other children in households of children diagnosed with $\mathrm{TB}$ and screening parents accompanying a child diagnosed with $\mathrm{TB}$.

Several interventions incorporated chest camps for awareness raising (NTP Wave 1) and as part of screening campaigns but used different approaches such as street theatre and infotainment for awareness raising (ASD Wave 2), outreach with sputum collection facilities, or with mobile x-rays. The NTP Pakistan Wave 1 project coupled the chest camps with private sector engagement and frontloaded sputum collection to deliver results quickly to people with 
presumptive TB. These different processes showcase successful deployment of trained lay personnel for screening, engagement of trained health workers in active case finding and the utilization of mobile teams for screening in community settings.

\section{Product innovations}

The two product innovation grants focused on developing a user-configurable mHealth application for TB data and establishment of DST at national TB reference laboratory (NTRL) using microbroth dilution for rifampicin resistant (RR)/MDR-TB patients being treated with any of the new or repurposed drug/s for measuring effectiveness of the treatment regimen and early detection of drug resistance.

\section{Empowering women and girls}

More recent interventions have also focused on empowering women and girls for instance through engaging the female community health workforce (lady health workers) in screening campaigns (Mercy Corps Wave 5) (14); training school girls to identify those with TB symptoms via the Kiran Sitara program (Interactive Research and Development Wave 7) or engaging female doctors in tele-health to provide healthcare to those in rural areas with limited access to services (Community Health Solution Wave 7). Along with TB innovations, these projects incorporate data or gender responsive interventions and women empowerment into TB programming. These interventions contribute to building the capacity of women and girls locally, in line with the Framework for the Empowerment of Women and Girls in TB REACH Grants (26) and the Canadian Government's Feminist International Assistance Policy (27) which recognizes the role that social development will have on health for all and the important role women play in development.

Overall, the 21 interventions implemented over the course of 10 years have included a diverse array of strategies for improving detection, linkage to treatment and reporting of TB. Some of these strategies include contact investigation through trained community health workers within households and at outreach camps, outreach camps using mobile $X$-rays in rural communities, incentivising doctors and community health workers for screening and linking people to care, linkage with allied health providers such as pharmacies, qualified hakim and homeopath practitioners and qualified birth attendant outlets and establishment of sputum collection and onsite diagnosis facilities in correctional facilities, reduction in market prices of diagnostic tests available in the private sector (IPAQT(28)) and social enterprise models for the private sector. In addition to these case finding strategies, interventions also included informational campaigns using infotainment in the form of street theatres and mass media campaigns for awareness raising.

Table 2 Summary of TB REACH innovations in Pakistan

\begin{tabular}{|c|c|c|c|c|c|}
\hline $\begin{array}{l}\text { Wa } \\
\text { ve }\end{array}$ & Organization & $\begin{array}{l}\text { Key } \\
\text { populations } \\
\text { screened }\end{array}$ & Process & Technology & $\begin{array}{l}\text { Publication } \\
\mathrm{s}^{*}\end{array}$ \\
\hline 1 & $\begin{array}{l}\text { Bridge } \\
\text { Consultants } \\
\text { Foundation } \\
\end{array}$ & Contacts & $\begin{array}{l}\text { Active contact investigation } \\
\text { through trained community } \\
\text { mobilizers and treatment support }\end{array}$ & & (12) \\
\hline 1 & $\begin{array}{l}\text { The Indus } \\
\text { Hospital }\end{array}$ & $\begin{array}{l}\text { Private sector } \\
\text { attendees in } \\
\text { urban settings }\end{array}$ & $\begin{array}{l}\text { Systematic screening in private } \\
\text { sector with using community } \\
\text { health workers for screening } \\
\text { patients }\end{array}$ & $\begin{array}{l}\text { Mobile banking to } \\
\text { provide incentives, } \\
\text { mHealth data } \\
\text { capture, GeneXpert } \\
\text { (year 2) }\end{array}$ & $\begin{array}{l}(20,22,29,30 \\
\end{array}$ \\
\hline 1 & $\begin{array}{l}\text { National TB } \\
\text { Programme }\end{array}$ & $\begin{array}{l}\text { Urban slum } \\
\text { dwellers }\end{array}$ & $\begin{array}{l}\text { Outreach camps and GPs trained } \\
\text { on TB screening, frontloaded } \\
\text { sputum collection }\end{array}$ & & (15) \\
\hline 1 & $\begin{array}{l}\text { Punjab } \\
\text { Prisons }\end{array}$ & Prisoners & $\begin{array}{l}\text { First time labs were set up in } \\
\text { many prisons for onsite diagnosis } \\
\text { and systematic screening as } \\
\text { opposed to passive case finding } \\
\text { with referral for testing }\end{array}$ & & \\
\hline
\end{tabular}




\begin{tabular}{|c|c|c|c|c|c|}
\hline 2 & $\begin{array}{l}\text { Interactive } \\
\text { Research and } \\
\text { Development }\end{array}$ & $\begin{array}{l}\text { Private sector } \\
\text { attendees in } \\
\text { urban settings }\end{array}$ & $\begin{array}{l}\text { Lay worker systematic TB } \\
\text { screening in private labs }\end{array}$ & $\begin{array}{l}\text { GeneXpert. mobile } \\
\text { phone-based data } \\
\text { capture and } \\
\text { reporting system }\end{array}$ & (23) \\
\hline 2 & $\begin{array}{l}\text { Association } \\
\text { for Social } \\
\text { Development }\end{array}$ & $\begin{array}{l}\text { Rural } \\
\text { population } \\
\text { with poor } \\
\text { access to care }\end{array}$ & $\begin{array}{l}\text { Street theatre performance and } \\
\text { chest camps with infrastructure } \\
\text { support to weak health systems }\end{array}$ & & (31) \\
\hline 3 & $\begin{array}{l}\text { Interactive } \\
\text { Research and } \\
\text { Development }\end{array}$ & $\begin{array}{l}\text { Private sector } \\
\text { attendees in } \\
\text { urban settings }\end{array}$ & $\begin{array}{l}\text { Social enterprise for the private } \\
\text { sector including setting up new } \\
\text { private clinics, integrated lung } \\
\text { health screening }\end{array}$ & $\begin{array}{l}\text { Digital CXR, } \\
\text { artificial intelligence } \\
\text { for reading CXR, } \\
\text { data collection } \\
\text { through mobile app }\end{array}$ & $(24,25,32)$ \\
\hline 3 & $\begin{array}{l}\text { National TB } \\
\text { Programme }\end{array}$ & Contacts & $\begin{array}{l}\text { GIS for contact tracing and } \\
\text { expanding contacts outside the } \\
\text { household }\end{array}$ & GIS mapping & (13) \\
\hline 4 & $\begin{array}{l}\text { The Indus } \\
\text { Hospital }\end{array}$ & Children & $\begin{array}{l}\text { Systematic screening in hospitals, } \\
\text { clinical training, contact tracing } \\
\text { and reverse contract tracing, and } \\
\text { preventative TB treatment }\end{array}$ & $\begin{array}{l}\text { SMS reminders were } \\
\text { sent to patients } \\
\text { concerning } \\
\text { appointments and to } \\
\text { promote adherence } \\
\text { to their treatment. }\end{array}$ & (33-35) \\
\hline 5 & $\begin{array}{l}\text { Interactive } \\
\text { Health } \\
\text { Solutions } \\
\end{array}$ & & & $\begin{array}{l}\text { A user-configurable } \\
\text { mHealth application } \\
\text { for TB data }\end{array}$ & \\
\hline 5 & $\begin{array}{l}\text { Bridge } \\
\text { Consultants } \\
\text { Foundation }\end{array}$ & $\begin{array}{l}\text { Transgender } \\
\text { women and } \\
\text { male sex } \\
\text { workers }\end{array}$ & $\begin{array}{l}\text { Partnering with local NGOs } \\
\text { working with key populations, } \\
\text { outreach camps and screening by } \\
\text { outreach workers, }\end{array}$ & & $(16,17)$ \\
\hline 5 & Mercy Corps & $\begin{array}{l}\text { Contacts, rural } \\
\text { populations }\end{array}$ & $\begin{array}{l}\text { Community-based household } \\
\text { screening by lady health workers }\end{array}$ & & $(14,36)$ \\
\hline 6 & $\begin{array}{l}\text { DOPASI } \\
\text { Foundation }\end{array}$ & $\begin{array}{l}\text { Coal miners, } \\
\text { their families, } \\
\text { and } \\
\text { communities }\end{array}$ & $\begin{array}{l}\text { Digital x-ray, chest camps, and } \\
\text { contact tracing }\end{array}$ & Fuji film Xair X-ray & \\
\hline 6 & $\begin{array}{l}\text { The } \\
\text { Foundation } \\
\text { for Innovative } \\
\text { New } \\
\text { Diagnostics }\end{array}$ & $\begin{array}{l}\text { People who } \\
\text { attend private } \\
\text { labs for } \\
\text { diagnosis }\end{array}$ & $\begin{array}{l}\text { Launching an Initiative for } \\
\text { Promoting Affordable and } \\
\text { Quality TB Tests (IPAQT) (28) in } \\
\text { Pakistan }\end{array}$ & & \\
\hline 6 & $\begin{array}{l}\text { The Indus } \\
\text { Hospital }\end{array}$ & $\begin{array}{l}\text { People with } \\
\text { EPTB in rural } \\
\text { areas }\end{array}$ & $\begin{array}{l}\text { Comprehensive diagnostic testing } \\
\text { of EP samples }\end{array}$ & & \\
\hline 7 & $\begin{array}{l}\text { Community } \\
\text { Health } \\
\text { Solutions }\end{array}$ & $\begin{array}{l}\text { Rural } \\
\text { population } \\
\text { with poor } \\
\text { access to care }\end{array}$ & $\begin{array}{l}\text { TB screening and diagnostic tele- } \\
\text { health consultations for patients } \\
\text { who have been referred to the } \\
\text { Primary Care Hub } \\
\text { RSPN-led household visits for } \\
\text { verbal screening }\end{array}$ & Tele-health & \\
\hline
\end{tabular}




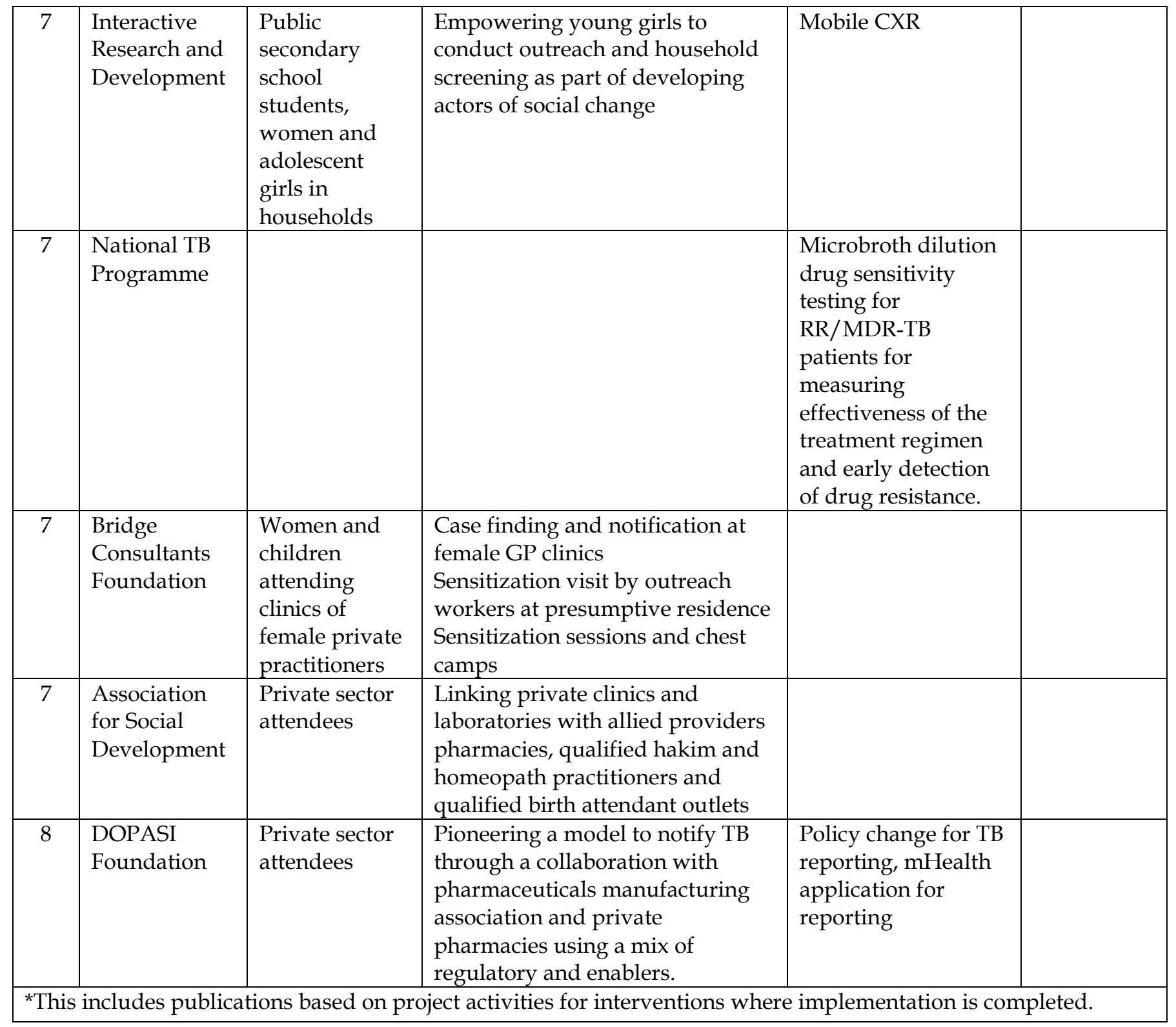

\section{Discussion}

TB REACH is a competitive funding mechanism focusing on innovation in the TB response. Each call for applications has solicited hundreds of letters of intent with less than $7 \%$ of applications being funded. Over the eight waves, the number of applications from Pakistan was higher than all other countries except India, and organisations, both public and private, in Pakistan have secured more funding (USD 13.4 million) than those in any other country speaking to the diversity and originality of ideas being produced.
Support of the National and Provincial TB programs has been essential to embrace new ideas, support different approaches, and pilot different strategies. At the same time, NGO partners have been able to use the TB REACH mechanism to fund new approaches that would have been difficult or impossible to begin using funding from the Global Fund or other large donors. Grantees from Pakistan have successfully demonstrated impact and managed to secure scale-up funds for continuation of activities into the second year and larger-scale service delivery. 


\section{Informing policy}

Results from TB REACH interventions have been used to inform national policies in Pakistan. TB REACH projects in Pakistan have published more than 20 peer reviewed articles on their results with a number of others waiting as projects finish data collection (where available, publications are listed in Table 1). These results help provide evidence for local and global policy. As documented in Pakistan's National Strategic Plan (NSP), Indus hospital's Wave 1 screening intervention doubled case detection in one year and resulted in the hospital becoming the second largest reporting centre in Pakistan (21). In 2013, the contact screening intervention implemented by the NTP detected more than 3,000 individuals with TB with a significant number with MDR-TB. These findings led the NTP to implement a new screening system, expanding the screening to household contacts of MDR-TB patients. This strategy was employed in three high burden PMDT sites (21). Discussions are underway for revising the curriculum of LHWs to include active case finding as a result of the impact demonstrated by the Wave 5 Mercy Corps intervention.

TB REACH projects in Pakistan have not only had impact locally, but have also influenced global policy and guidance formulations such as the WHO's operational manual on Xpert MTB/RIF implementation (37), guide on systematic screening for active tuberculosis (38), best practices in child and adolescent tuberculosis care (39) and the landscape analysis for engaging private health care providers in TB care and prevention: a landscape analysis (19). The latest guidance from $\mathrm{WHO}$ on screening for TB includes a number of new technologies such as artificial intelligence for CXR reading, where TB $\mathrm{REACH}$ projects were the first to use and evaluate the technology and have produced evidence to inform the WHO guidance (40).

\section{Coordination}

Although TB REACH grantees in Pakistan had been meeting at annual grantee workshops organised by the TB REACH secretariat, in 2017 Stop TB Pakistan (National Partnership) took the initiative to formalise these interactions and provided a platform for grantees to interact at regular intervals. The Coordination Group for TB REACH grantees facilitates a link between TB REACH grantees and NTP and the PTPs; bridges the gap between implementation research and policy so that successful interventions are scaled up and TB policies at national and provincial levels reflect the lessons learnt from TB $\mathrm{REACH}$ grants; provides technical and advocacy support to grantees in a timely manner to ensure smooth implementation of the projects. To this effect, Stop TB Pakistan has organised a workshop on proposal writing for NGOs as well as the public sector.

TB REACH has been able to support the early introduction of a number of tools in Pakistan that have then been adopted and scaled up through other donor funding. For instance projects have supported the first use of AI for CXR reading which is now being supported by the Global Fund and is the largest such approach in the world (41).

The focus on key populations has allowed grantees to test and showcase approaches that work for most at risk groups and those with limited access to TB services. These successful approaches have been scaled-up to allow for a wider reach to marginalised groups such as transgender women and MSWs. The focus on empowering women and girls in recent Waves will shed light on the links between gender issues in affected communities and the TB response and allow piloting of responsive interventions to address identified gaps. The approaches that demonstrate impact on key populations can then be incorporated into other local and international initiatives for sustained implementation and scale-up. Although previous TB REACH interventions in Pakistan have demonstrated innovative approaches to engage private providers (e.g. via social enterprise models), there is room for engaging informal, allied health providers and results from the currently ongoing Wave 7 and 8 interventions that seek to engage these informal providers will be useful in designing the private sector engagement strategy going forward. Current funding from USAID has focused on PPE and developing and evaluating different approaches for scale-up.

\section{Conclusion}

The TB response in Pakistan and globally will continue to require innovation and disruption to improve the delivery to all people with TB. As we continue the efforts towards ending TB, there is a need to stimulate innovative local solutions, especially as Covid threatens to halt the gains made in the last few years. There is a pressing need to incorporate learning from pilot projects into local policy and to learn from 
the lessons of previous implementers to streamline the care available for those most affected by TB. We hope the spirit of innovation to policy can continue in Pakistan and look forward to new ideas to reach all people in need. As TB REACH looks to consolidate a new round of funding from donors, the continued drive for testing new ideas and evaluating them under programmatic conditions is needed and we look forward to new projects and approaches.

\section{References}

1. WHO. Global tuberculosis report 2019 [Internet]. WHO. Geneva: World Health Organization; 2019 Oct [cited 2020 Aug 14]. Available from: http://www.who.int/tb/publications/global_report/e $\mathrm{n} /$

2. Stop TB. The Global Plan to End TB 2018-2022 [Internet]. Geneva; 2019 [cited 2020 Aug 14]. Available from: http://www.stoptb.org/global/plan/plan1822.asp

3. Ho J, Fox GJ, Marais BJ. Passive case finding for tuberculosis is not enough. Vol. 5, International Journal of Mycobacteriology. Elsevier Ltd; 2016. p. 374-8.

4. Lönnroth K, Corbett E, Golub J, Godfrey-Faussett P, Uplekar M, Weil D, et al. Systematic screening for active tuberculosis: Rationale, definitions and key considerations [Internet]. Vol. 17, International Journal of Tuberculosis and Lung Disease. Int J Tuberc Lung Dis; 2013 [cited 2020 Aug 4]. p. 289-98. Available from: https://pubmed.ncbi.nlm.nih.gov/23407219/

5. Pai M. Innovations in Tuberculosis Diagnostics: Progress and Translational Challenges [Internet]. Vol. 2, EBioMedicine. Elsevier; 2015 [cited 2020 Aug 4]. p. 1823. Available from: https://www.ncbi.nlm.nih.gov/pmc/articles/PMC448 $4823 /$

6. Stop TB Partnership | TB REACH [Internet]. [cited 2020 Aug 7]. Available from: http://www.stoptb.org/global/awards/tbreach/

7. Stop TB Partnership | Board Meeting 11-12 December 2019, Jakarta, Indonesia [Internet]. 2019 [cited 2020 Aug 14]. Available from: http://www.stoptb.org/about/cb/meetings/32/

8. Creswell J, Sahu S, Blok L, Bakker MI, Stevens R, Ditiu L. A Multi-Site Evaluation of Innovative Approaches to Increase Tuberculosis Case Notification: Summary Results. Hoshino Y, editor. PLoS One [Internet]. 2014 Apr 10 [cited 2020 Aug 4];9(4):e94465. Available from: https://dx.plos.org/10.1371/journal.pone.0094465

9. Blok L, Sahu S, Creswell J, Alba S, Stevens R, Bakker MI. Comparative Meta-Analysis of Tuberculosis Contact Investigation Interventions in Eleven High Burden Countries. Merler S, editor. PLoS One [Internet]. 2015 Mar 26 [cited 2020 Aug 4];10(3):e0119822. Available from: https://dx.plos.org/10.1371/journal.pone.0119822

10. Creswell J, Codlin AJ, Andre E, Micek MA, Bedru A, Carter EJ, et al. Results from early programmatic implementation of Xpert MTB/RIF testing in nine countries. BMC Infect Dis [Internet]. 2014 Jan 2 [cited 2020 Aug 4];14(1):2. Available from: https://bmcinfectdis.biomedcentral.com/articles/10.11 86/1471-2334-14-2

11. Blok L, Creswell J, Stevens R, Brouwer M, Ramis O, Weil $\mathrm{O}$, et al. A pragmatic approach to measuring, monitoring and evaluating interventions for improved tuberculosis case detection. Int Health [Internet]. 2014 Aug 6 [cited 2020 Aug 4];6(3):181-8. Available from: https:/ / dx.doi.org/10.1093\%2Finthealth\%2Fihu055

12. Shah SA, Qayyum S, Abro R, Baig S, Creswell J. Active contact investigation and treatment support: An integrated approach in rural and urban Sindh, Pakistan. Int J Tuberc Lung Dis. 2013 Dec 1;17(12).

13. Fatima R, Qadeer E, Yaqoob A, Haq M ul, Majumdar SS, Shewade HD, et al. Extending 'Contact Tracing' into the Community within a 50-Metre Radius of an Index Tuberculosis Patient Using Xpert MTB/RIF in Urban, Pakistan: Did It Increase Case Detection? Chaturvedi V, editor. PLoS One [Internet]. 2016 Nov 29 [cited 2020 Aug 5];11(11):e0165813. Available from: https://dx.plos.org/10.1371/journal.pone.0165813

14. Rashid A, Naureen F, Ali S, Anjum N, Fatima I, Noor A. Engagement of lady health workers to enhance tuberculosis case notification in rural Sindh, Pakistan. Abstract from the 49th World Conference on Lung Health of the International Union Against Tuberculosis and Lung Disease (The Union), The Hague, 24-27 Oct. Int J Tuberc Lung Dis [Internet]. 2018;22(11):S477. Available from: https://www.theunion.org/what-wedo/journals/ijtld/body/TheUnion2018_Abstracts_Web .pdf

15. Fatima R, Qadeer E, Enarson DA, Creswell J, Stevens R, Hinderaker SG, et al. Success of active tuberculosis case detection among high-risk groups in urban slums in Pakistan. Int J Tuberc Lung Dis. 2014 Sep 1;18(9):1099_ 104.

16. Shah S, Khattak W, Farrukh N. Public-private partnership to enhance access of key populations to public sector health facilities for diagnosis and treatment of tuberculosis. Abstract from the 49th World Conference on Lung Health of the International Union Against Tuberculosis and Lung Disease (The Union), The Hague, 24-27 October 2018. Int J Tuberc Lung Dis [Internet]. 2018 Nov [cited 2020 Aug 14];22(11; Suppl 2):S398-9. Available from: https://www.theunion.org/what-wedo/journals/ijtld/body/TheUnion2018_Abstracts_Web .pdf

17. Shah $S$. Active TB case finding among transgender and male sex workers in Pakistan. Abstract from the 49th World Conference on Lung Health of the International 
Innovative approaches to end TB in Pakistan: a review of TB REACH projects from 2010 to 2020

Union Against Tuberculosis and Lung Disease (The Union), The Hague, 24-27 October 2018. Int J Tuberc Lung Dis [Internet]. 2018 Nov [cited 2020 Aug 14];22(11; Suppl 2):S43. Available from: https://www.theunion.org/what-wedo/journals/ijtld/body/TheUnion2018_Abstracts_Web .pdf

18. Creswell J, Khan A, Bakker MI, Brouwer M, Kamineni VV, Mergenthaler $C$, et al. The TB REACH Initiative: Supporting TB Elimination Efforts in the Asia-Pacific. Trop Med Infect Dis. 2020;5(4):164.

19. WHO. Engaging private health care providers in TB care and prevention: a landscape analysis [Internet]. WHO. Geneva: World Health Organization; 2018 [cited 2020 Aug 7]. Available from: http://www.who.int/tb/publications/2018/PPMlands cape/en/

20. Khan AJ, Khowaja S, Khan FS, Qazi F, Lotia I, Habib A, et al. Engaging the private sector to increase tuberculosis case detection: An impact evaluation study. Lancet Infect Dis [Internet]. 2012 Aug 1 [cited 2020 Aug 4];12(8):608-16. Available from: http://www.thelancet.com/article/S1473309912701160 /fulltext

21. National End TB Strategic Plan 2017-2020 [Internet]. Islamabad; 2017 [cited 2020 Aug 15]. Available from: http://phkh.nhsrc.pk/sites/default/files/2019-

06/National End TB Strategic Plan 2017-20.pdf

22. Creswell J, Khowaja S, Codlin A, Hashmi R, Rasheed E, Khan M, et al. An Evaluation of Systematic Tuberculosis Screening at Private Facilities in Karachi, Pakistan. Aziz SA, editor. PLoS One [Internet]. 2014 Apr 4 [cited 2020 Aug 5];9(4):e93858. Available from: https://dx.plos.org/10.1371/journal.pone.0093858

23. Codlin AJ, Javaid M, Qazi F, Khan MS. Novel methodology to assess sputum smear microscopy quality in private laboratories. BMC Infect Dis [Internet]. 2012 Nov 29 [cited 2020 Aug 5];12(1):331. Available from: https://bmcinfectdis.biomedcentral.com/articles/10.11 86/1471-2334-12-331

24. Zaidi SMA, Habib SS, Van Ginneken B, Ferrand RA, Creswell J, Khowaja S, et al. Evaluation of the diagnostic accuracy of Computer-Aided Detection of tuberculosis on Chest radiography among private sector patients in Pakistan. Sci Rep [Internet]. 2018 Dec 1 [cited 2020 Aug 5];8(1):12339. Available from: www.nature.com/scientificreports

25. Habib SS, Rafiq S, Zaidi SMA, Ferrand RA, Creswell J, Van Ginneken B, et al. Evaluation of computer aided detection of tuberculosis on chest radiography among people with diabetes in Karachi Pakistan. Sci Rep [Internet]. 2020 Dec 1 [cited 2020 Aug 5];10(1):1-5. Available from: https://doi.org/10.1038/s41598-02063084-7

26. Framework for the Empowerment of Women and Girls in TB REACH Grants [Internet]. [cited 2020 Aug 14]. Available from: http://www.stoptb.org/assets/documents/global/aw ards/tbreach/W7_WEmpowerment_TBREACHGrants. pdf

27. Canada's Feminist International Assistance Policy [Internet]. [cited 2020 Aug 14]. Available from: https://www.international.gc.ca/worldmonde/issues_developmentenjeux_developpement/priorities-priorites/policypolitique.aspx?lang=eng

28. IPAQT - Alliance for Better Diagnostics [Internet]. [cited 2020 Aug 7]. Available from: http://ipaqt.pk/

29. Hussain H, Mori AT, Khan AJ, Khowaja S, Creswel J, Tylleskar $\mathrm{T}$, et al. The cost-effectiveness of incentivebased active case finding for tuberculosis (TB) control in the private sector Karachi, Pakistan. BMC Health Serv Res [Internet]. 2019 Oct 12 [cited 2020 Aug 5];19(1):690. Available from: https:/ / bmchealthservres.biomedcentral.com/articles/ 10.1186/s12913-019-4444-z

30. Dowdy DW, Lotia I, Azman AS, Creswell J, Sahu S, Khan AJ. Population-Level Impact of Active Tuberculosis Case Finding in an Asian Megacity. Kranzer K, editor. PLoS One [Internet]. 2013 Oct 16 [cited 2020 Aug 5];8(10):e77517. Available from: https://dx.plos.org/10.1371/journal.pone.0077517

31. Khan MA, Anil S, Ahmed M, Athar A, Ghafoor A, Brouwer M. Active Case Finding of Tuberculosis: Randomized Evaluation of Simple and Infotainment Chest Camps. Ann Glob Heal. 2016 Sep 1;82(5):813-8.

32. Habib SS, Rafiq S, Jamal WZ, Ayub SM, Ferrand RA, Khan A, et al. Engagement of private healthcare providers for case finding of tuberculosis and diabetes mellitus in Pakistan. BMC Health Serv Res. 2020;20(1):18.

33. Malik AA, Hussain H, Creswell J, Siddiqui S, F. Ahmed J, Madhani F, et al. The Impact of Funding on Childhood TB Case Detection in Pakistan. Trop Med Infect Dis [Internet]. 2019 Dec 15 [cited 2020 Aug 5];4(4):146. Available from: https://www.mdpi.com/2414-6366/4/4/146

34. Amanullah F, Malik AA. Unmasking childhood tuberculosis in Pakistan: Efforts to improve detection and management. Int J Tuberc Lung Dis. 2015 Dec 1;19(12):S47-9.

35. Malik AA, Amanullah F, Jaswal M, Siddiqui S, Ahmed $\mathrm{J}$, Creswell J, et al. High yields from contact investigation of child index TB patients. Int $\mathrm{J}$ Tuberc Lung Dis. 2020;24(8):850-2.

36. Khan MS, Mehboob N, Rahman-Shepherd A, Naureen F, Rashid A, Buzdar N, et al. What can motivate Lady Health Workers in Pakistan to engage more actively in tuberculosis case-finding? BMC Public Health [Internet]. 2019 Jul 25 [cited 2020 Aug 5];19(1). Available from: /pmc/articles/PMC6657372/?report=abstract 
37. WHO. Xpert MTB/RIF implementation manual [Internet]. WHO. Geneva: World Health Organization; 2014 [cited 2020 Aug 7]. Available from: https://www.who.int/tb/publications/xpert_implem_ manual/en/

38. WHO. Systematic screening for active tuberculosis: an operational guide [Internet]. WHO. Geneva: World Health Organization; 2015 [cited 2020 Aug 7]. Available from:

http://www.who.int/tb/publications/systematic_scree ning/en/

39. WHO. Best practices in child and adolescent tuberculosis care [Internet]. WHO. Geneva: World
Health Organization; 2018 [cited 2020 Aug 7]. Available from: http://www.who.int/tb/publications/2018/bestpractices-child-adolescent-TB-care/en/

40. WHO. Rapid communication on systematic screening for tuberculosis. Geneva; 2020.

41. Madhani F, Maniar RA, Burfat A, Ahmed M, Farooq S, Sabir A, et al. Automated chest radiography and mass systematic screening for tuberculosis. Int J Tuberc Lung Dis [Internet]. 2020 Jul 1 [cited 2020 Aug 15];24(7):66573. Available http://www.ncbi.nlm.nih.gov/pubmed/32718398 